Check for updates

Washington, DC, USA

bobroehr@aol.com

Cite this as: BMJ 2020;369:m2333 http://dx.doi.org/10.1136/bmj.m2333 Published: 22 June 2020

\section{Covid-19 is threatening the survival of US primary care}

\section{In the US, government imposed lockdowns and public fears have slashed primary care visits-and with it revenue for physicians, Bob Roehr reports}

\section{Bob Roehr science journalist}

This is an especially difficult time to be a GP, internist, paediatrician, or other physician providing primary care in the US. "To be honest, independent primary care was struggling long before this pandemic came along,” primary care provider (PCP) Leto Quarles wrote on the popular MedPage Today blog KevinMD. But it's recently become much worse. Since the pandemic hit, "revenues are way down and the bills that I can't pay are piling up,” Quarles wrote. ${ }^{1}$

Quarles's concerns are shared across the country.

In the US, primary care accounts for only $6-8 \%$ of all healthcare expenditure, compared with an average of $12 \%$ in most other developed countries. ${ }^{2}$ PCPs make far less than other US specialists, \$243000 (£192 000; $€ 214$ 00o) annually compared with a specialist's average income of $\$ 346$ ooo, according to Medscape's Physician Compensation Report 2020. ${ }^{3}$ PCPs often work in rural and other underserved populations and rely primarily on fee-for-service payments. Like most Americans, they are only a few missed pay days away from a financial crisis.

Even before covid-19 hit, visits to primary care providers were on a steep decline, dropping by nearly a quarter (24.2\%) over the period 2008-2016, according to a recent study of patients with commercial health insurance. ${ }^{4}$

In those same eight years, visits to alternative care sites, such as emergency departments and retail medical clinics, ${ }^{5}$ grew by nearly half (46.9\%). Many, including the more than 1000 "Minute Clinics" of the drug store chain CVS, depend on physicians' assistants and nurses for care delivery, instead of PCPs. Convenience of location and operating hours, and often lower prices for basic services such as prescribing antibiotics, have chipped away at the volume of services and revenue that typically went to independent PCPs.

\section{Problems mount}

Public attention during the pandemic has focused on hospitals; that's where the challenge is greatest, the personal drama highest, and where people are dying. Meanwhile, however, the feeder system to those hospitals, the PCPs-the ones public service announcements refer to when they say "see your doctor"-is collapsing.

After the SARS-CoV-2 virus hit, visits to PCPs plummeted even more steeply-to below half of what they were the year before-because of stay at home orders and fear of catching the virus. The numbers had recovered modestly by mid-May ${ }^{6}$ to about a third lower than what is typical, according to weekly monitoring of practice software developed by Phreesia, a technology company that provides those services to about $5 \%$ of all ambulatory care practices

"Patients and communities, especially those that are underserved and under siege because of covid-19, cannot afford widespread closures of community based care practices," the American Academy of Family Physicians (AAFP) and others wrote in a letter to health secretary Alex Azar on 19 May. It noted that $40 \%$ of its member practices had laid off or furloughed staff. ${ }^{7}$

PCPs face operational challenges as well. They often lack established access to supplies of the personal protective equipment that is currently needed, and they do not have the clout or bulk discounts of hospital systems to secure equipment in short supply. Nor do they have the time and staff to disinfect facilities between patients or alter their physical space to practise social distancing. At present, the problems continue, they have not been completely resolved.

Most independent PCPs lack the resources and training to fully implement and integrate telemedicine into their practice. Rural practitioners, especially, may face poor internet access. And not all patients are technically savvy, particularly older people with complex conditions.

The AAFP argued in its letter that its physician members have either been excluded or are unable to comply with the bureaucratic requirements for assistance, which has resulted in the limited assistance to date. They sought administrative relief-whether they get it remains to be seen.

\section{Phantom relief}

The federal government's Centers for Medicare and Medicaid Services (CMS) gave loans to help ease the cash flow crisis caused by covid-19 within the healthcare system. But by 2 May, more than $80 \%$ of the $\$ 1$ oobn had gone to hospitals. ${ }^{8}$ Family practice received the smallest crumb of the 15 categories of recipients-just $\$ 15 \mathrm{~m}$ of the $\$ 1$ obn, according to a compilation of outlays done by Modern Healthcare. ${ }^{9}$

In response to covid-19, AAFP and its allies have called for a "primary care Marshall Plan," ${ }^{10}$ invoking the name of the US effort that helped to rebuild the economies of Europe after the second world war. The proposal builds upon the government's own already existing plan, Primary Care First, ${ }^{11}$ a CMS innovation unveiled last spring that entails "a set of voluntary five year payment options that reward value and quality by offering an innovative payment structure to support delivery of advanced primary care.” 
CMS is rolling out the plan; applications to participate are open in 26 of the 50 states and reimbursement under the plan will begin in January 2021. But in light of the stresses to providers brought on by the pandemic, supporters are calling for accelerated and expanded implementation of this approach to help save primary care.

"We need to throw these practices a lifeline. Right now," Farzad Mostashari said in a press briefing in May organised by the think tank the Commonwealth Fund. He is chief executive of Aledade, a technology company that assists small practices. He criticised fee-for-service payments. "We have been paying for primary care the wrong way," he said, urging the switch to a flat annual fee per patient for all primary care.

Additionally, Mostashari proposed immediately dispensing \$15bn to PCPs, roughly what CMS spends on primary care over a four month period. "It is really not much when you compare it to what is spent on the failures of primary care, when a medical condition is not tackled early but advances to a more advanced and costly stage."

At the same briefing, Mehrotra supported the idea. "I am afraid that practices will not reopen-and also afraid that they will feel that they have to serve their communities and will reopen, even if they do not have adequate supplies to protect themselves and their staff.”

Competing interests: I have read and understood BMJ policy on declaration of interests and have no relevant interests to declare.

1 Quarles L. I'm a physician during covid: don't ask me how l'm doing. 21 May 2020. www.medpagetoday.com/blogs/kevinmd/86616?xid=n__secondopinion_2020-05-26\&eun=g409298dOr.

2 Patient Centred Primary Care Collaborative. Spending for primary care. www.pcpcc.org/sites/default/files/re-

sources/PCPCC\%20Fact\%20Sheet\%20PC\%20Spend\%20Aug\%202018.pdf.

3 Kane L.Medscape physician compensation report 2020. May 2020.www.medscape.com/slideshow/2020-compensation-overview-6012684\#1.

4 Ganguli I, Shi Z, Orav EJ, Rao A, Ray KN, Mehrotra A. Declining use of primary care among commercially insured adults in the United States, 2008-2016. Ann Intern Med2020;172:240-7. doi: 10.7326/M19-1834 pmid: 32016285

5 Roehr B. US sees sharp rise in number of store based medical clinics. BMJ2012;344: doi: 10.1136/bmj.e4253 pmid: 22718960

6 Mehrotra A, Chernew M, Linetsky D, Hatch H, Cutler D. The impact of the covid-19 pandemic on outpatient visits: a rebound emerges. 19 May 2020. www.commonwealthfund.org/publications/2020/apr/impact-covid-19-outpatient-visits.

7 American Academy of Family Physicians. AAFP, others warn Azar of imminent primary care closures. 22 May 2020. www.aafp.org/news/government-medicine/20200522closurewarning.html.

8 Centers for Medicare and Medicaid Services. Medicare accelerated and advance payments. 8 May 2020. www.cms.gov/files/document/covid-accelerated-and-advance-payments-state.pdf.

9 Cohrs R. Hospitals get more than $80 \%$ of Medicare advance payments. May 2020. www.modernhealthcare.com/finance/hospitals-get-more-80-medicare-advance-payments?utm_source=modern-healthcare-covid-19-coverage\&utm_medium=email\&utm_campaign=20200520\&utm_content=article1-headline

10 Health Rosetta. Primary care Marshall Plan. https://healthrosetta.org/marshall-plan.

11 Centers for Medicare and Medicaid Services. Primary care first model options. https://innovation.cms.gov/innovation-models/primary-care-first-model-options.

\footnotetext{
This article is made freely available for use in accordance with BMJ's website terms and conditions for the duration of the covid-19 pandemic or until otherwise determined by BMJ. You may use, download and print the article for any lawful, non-commercial purpose (including text and data mining) provided that all copyright notices and trade marks are retained.
} 